\title{
CUSTOMER SERVICE ORIENTATION ON ADHESION CONTRACTS
}

Murielle C. G. R. Câmara Potiguar University, Brazil E-mail: murielle@unp.br

Kleber Cavalcanti Nobrega Potiguar University, Brazil E-mail: klebercn@unp.br

Thereza A. B. S. Santos University Center of Rio Grande do Norte - UNI-RN, Brazil E-mail: therezangelica@gmail.com

Submission: 09/06/2015 Revision: 24/06/2015 Accept: 28/06/2017

\section{ABSTRACT}

Hiring a service is a moment of great importance once it builds perception of service value and quality. Some companies may deal with that, assuming a greater importance when elaborating their service contracts. Usually law professionals elaborate these documents, but this may prioritize legal attributes, not considering the customer service orientation, as well as the customers' point of view. In times of increasing on customer focus, market and service orientation, a question can be posted: to what extent company contracts show service or customer orientation? This paper compares the service orientation degree for Cable TV contracts from five companies, based on a theoretical model developed to this purpose. From a conceptual model for service-oriented contract, four dimensions were assessed: physical aspects, reasonableness, intelligibility and customer focus. After evaluation by eight judges, analyzing the content validation index $(\mathrm{CVI})$, it was found that the contracts show moderate orientation for serving. Furthermore, results show that the five surveyed company's contracts showed a similar overall performance, i.e., none stood out over the other. 
The study presents important practical efficacy, because it can guide Cable TV companies to adopt improvement strategies in elaboration of contracts, so that contractual instruments be would reviewed of clauses that promote the sensation of better service to their customer. Thus, this article directs managers to the aspects that deserve more attention, i.e., which dimensions require further refinement and serving orientation.

Keywords: Adhesion Contracts, Service Orientation, Customer oriented contract; service-oriented contract

\section{INTRODUCTION}

With service sector great evolution in many countries all over the world, a global change in focus of service provision has been noticed in last years, considering the competitiveness in the market and the need for the survival of the companies through periods of economic crisis. According to Kotler (2013), surviving companies will be those that understand target markets' needs and expectations, and, so, stand more capable than others to ensure customer satisfaction.

But business contracts tend to include, more and more, clauses which put customers in a dependent condition. Contracts carry on customers' duties in a greater proportion than their rights. This issue keeps relation with the use of the sense for serving (NÓBREGA, 2010). The author points two different attitudes for a company: to serve versus to be served.

Serving oriented companies are those which put themselves in a condition to better serve customers, having so, a customer serving orientation. Otherwise, there are company's products or self-oriented, transmitting an image that, when attending people, they seem to be interested only in financial results from transactions. This way, they act as if they want to be served by customers.

There is not, yet, a widely accepted term for these kind of postures. It is tempting make use of the term "servant contracts", but word relates to servility, slavery, inferiority. So, for the purpose of this paper, the terms "customer service oriented contract", and "serving orientation" will be preferably adopted.

Considering the moment of contracting a service, Marques (2005) highlights that, with industrial revolution and the significant population increase, contracts tend 
to be, more and more, mass contracts, signed as adhesion contract available to public in a uniform model, with unilaterally fixed clauses by the economically stronger contractual partner.

At the same time, services management presents a current approach beyond the simple service provision. The service package recognizes several dimensions that go beyond the service itself and analyze all aspects that permeate its installment, including accessories aspects, operational and psychological process (FITZSIMMONS; FITZSIMMONS, 2005).

Moreover, related to the sense of service, come the theoretical constructs for serving oriented company and serving oriented processes, in which indispensable characteristics that seek to facilitate user's life, like informative aspects, flexibility and customer focus (NOBREGA, 2009), have been considered.

So, if by one side there is a tendency for serving customers more and more, towards typified Silvestro's (1992) professional service, on the other hand, mass contracts seem to be more related to typified Silvestro's mass services, specially due to increasing volumes of customer contacts.

In this context, this present research is motivated by the confrontation of these two movements: to what extent operations with serving orientation matches serving orientation on contracts establishment?

Thus, this research presents a conceptual model for service oriented contracts characterization, and has, as major objective, to evaluate the existence and identify the level of serving orientation in adhesion contracts offered by Cable TV companies operating in a determined region.

\section{THEORETICAL FOUNDATION}

\subsection{Adhesion contract under the perspective of the consumer's right}

Contract refers to a bilateral legal act with at least one declaration of intent, which purpose is to create, modify or provide extinction of rights and duties. Classification related to this study refers to the categorization that considers the content negotiation by distinct parts. In this aspect, there are the parallel contracts, in which the involved parts have the opportunity to discuss previously their clauses. In counterpoint, there are adhesion contracts, in which terms are predetermined or 
INDEPENDENT JOURNAL OF MANAGEMENT \& PRODUCTION (IJM\&P)

http://www.ijmp.jor.br

v. 9, n. 1, January - March 2018

ISSN: 2236-269X

DOI: 10.14807/ijmp.v9i1.347

predisposed, like in the case of standard contract and contract forms. In these cases, one part imposes the negotiating content, leaving the other part, the adherence, with only two options: to accept or not to accept the standardized business content (TARTUCE, 2011).

Brazilian legal system, with the Consumer Protection Code, reinforced the concept of contractual balance, which reveals itself indispensable to the consumers relationships, considering the usual practice of mass contracts, through which service customers adhere to the terms and conditions established unilaterally by the supplier, without the opportunity of discussing contracts' content (BRAZIL, 2014).

It is noteworthy that, in contractual material, due to the balance between the parts, the customers, the consumers, service users, have the right to transparency and information at the time of contract, as well as the of legal relationship. In this sense, written adhesion contracts will be drafted in clear terms and with ostensible and legible characters, whose font size are not less than twelve, facilitating their understanding by the consumer (BRAZIL, 2014).

Furthermore, among the Principles of Contract Right, the Good Faith Principle stands out as it refers to the subjective concept of fair conduct of the contracting parts, as a duty to be attached to the obligations of the contract itself. According to Marques (2005), in contracts, the verification of the contractual good faith concerns the analysis of existence of abusive or excessively onerous clauses to the consumer, which in some cases, are subject to nullity.

On the other hand, the duty of loyalty, clarity and transparency do not mean burden to suppliers, since by legal imposition, contracts must ensure correct, clear, accurate, visible and characteristics like quality, quantity, composition, price, warranty, validity period and origin, among other dates, as well as the risks posed to health and safety of consumers (BRAZIL, 2014). Briefly, in the perspective of contractual protection given to consumers, a good adhesion contract must include, in a perfect way, four dimensions: Balance, Transparency, Clarity and Good Faith.

Balance dimension suggests the idea of equality of rights and constant contract obligations, so that it is proportional in terms of tax and duty to the customer and to the supplier. Transparency and Clarity dimensions are part of the inherent supplier's information duty, and remit to highlight any clause that suggests consumer 
INDEPENDENT JOURNAL OF MANAGEMENT \& PRODUCTION (IJM\&P)

http://www.ijmp.jor.br

v. 9, n. 1, January - March 2018

ISSN: 2236-269X

DOI: 10.14807/ijmp.v9i1.347

rights restriction, as well as the facilitation of information, so that the customer gets full access to the terms of the contract and, of course, for any service that he or she is hiring. Finally, good faith, principle of contractual right and basic dimension established by the Consumer Protection Code, reflects contractual duty of loyalty on both sides to service provider, the good faith is guided by the duty to be faithful to contract proposal, and not to offer excessive tax to contractor.

\subsection{Adhesion contract under the perspective of management service}

Service is an activity or set of activities characterized by certain intangibility offered as a solution to customers' problems or needs (GRÖNROOS, 2009). To Lovelock, Wirtz and Hemzo (2011, p. 21) services can be defined as "economic activities between two parts, involving an exchange of value between seller and buyer in a market".

Fitzsimmons and Fitzsimmons (2005, p. 30) conceptualize service claiming that it refers to a "perishable experience, intangible, developed for consumers who plays the role of co-producer". To Parasuraman (2006), services are not objects, but are provided through the performance of service providers. Thus, most services cannot be counted, measured, inventoried, tested and verified before the sale, to ensure quality. The referred author also states that, in the absence of tangible evidence, based on the evaluation of quality, the consumers evaluate other tips.

In Service Package, proposed by Fitzsimmons and Fitzsimmons (2005), services present tangible and intangible aspects under the tangible aspects, services are comprised of installations and equipment (support facilities), in other words, the available physical resources before offering the service and delivered materials (facilitators goods), which would be provided materials during the provision of service. Moreover, concerning the intangible aspect of service, service splits in service process (explicit services), i.e., activities and execution stages to attend customers' needs and expectations, and service product (implicit services) which would be the benefits, including psychological, which result from the process of service provision.

According to Nóbrega (2013), in a considerably special way, it is necessary to define service provision product, i.e., establish what sensation is needed to influence 
INDEPENDENT JOURNAL OF MANAGEMENT \& PRODUCTION (IJM\&P)

http://www.ijmp.jor.br

v. 9, n. 1, January - March 2018

ISSN: 2236-269X

DOI: 10.14807/ijmp.v9i1.347

the consumer. Therefore, it is necessary to put oneself in the customer's place as well as strengthening people training for the process of service provision.

There are several important and decisive moments in the relationship established between the service provider and the consumer. Among these important and decisive moments, one stands out, namely, the act of hiring. Although many companies do not consider it relevant, it is pacific that the act of hiring is, in many cases, moments of intense interaction, where the consumer will come across different nuances of the package that will make him or her decide whether to hire or not.

Therefore, for the contract to contribute to a positive psychological effect on the consumer, it must meet conditions that remit reliability, clarity, information, security, and fairness, among other sensations that benefit the customer on the act of hiring. The quoted requirements makes up Servqual dimensions theoretical construct proposed by Parasuraman, and Berry Zeithaml (1990), which applies to a concept of a good contract under the perspective of service management.

In adhesion contracts, tangibility can be verified when the contractual instrument contemplates the physical aspects, considering that the client meeting with the referred aspects may not have occurred at the time of contracting the service interpreting the reliability dimension as the ability to meet the promised. It is verified that, for the contract to achieve its purpose, to fulfill its promise, that is, establish and clearly state the terms of an agreement, it is necessary to present a simple language, conspicuous and legible characters, free of error and satisfactorily explain the technical terms. The security for contract purposes can be glimpsed when establishing a proportional number between clauses that present rights and obligations to the contractor, considering that it interferes with consumer expectations and his or her perspective of self-safety and self-conscious of not having only obligations. On the other hand, contractual responsiveness can be interpreted as a prediction deadline and the expectation that the service will be held within a reasonable time, since it is solution to any customer's problem. And finally, empathy can be glimpsed in the contract when it contemplates, a personalized service to its customers.

\subsection{Adhesion contract under the perspective of sense of serving}


INDEPENDENT JOURNAL OF MANAGEMENT \& PRODUCTION (IJM\&P)

http://www.ijmp.jor.br

v. 9, n. 1, January - March 2018

ISSN: 2236-269X

DOI: 10.14807/ijmp.v9i1.347

Reflecting service concept in an etymological context, the word "serve" suggests subservience, slavery, servant character, among others, so, it is possible to glimpse the necessity of the organization to adopt a "spirit of service," where it is possible to identify customers' necessities and attend them consequently (NÓBREGA; RIBEIRO; MARQUES, 2006).

Yoshimura (1996) calls "spirit of service" the behaviors that reveal sensation of well being to the customer, through readiness, cordial attitude, willingness to help, which does not necessarily mean subservience or inferiority behavior.

Molnar (2007) states that serving leadership relates to the concept of an ethic based on virtue, which emphasizes the agent's personal moral character. Nóbrega, Ribeiro and Marques (2006, p.3) define serving as "performing activities with the aim of providing benefit to those who are being served". The strategy, with the aim of satisfying the customers, therefore, inserts itself as the organization's behavior modification tool.

In this sense, it is important that servant behavior in organizations develops itself spontaneously, without sense of obligation and ensures transformation and personal growth of those involved (ZEITHAML; BITNER, 2003).

So, what can be pointed as servant behavior? Nóbrega (2009) lists some attributes for the servant behavior, including responsibility, simplicity, renunciation, initiative, willingness to help, welfare practice and utility.

In this sense, analyzing the strategic option for the sense of serving, Nobrega (2009) idealized the theoretical construct of serving oriented company, through which the sense of serving is revealed by the union of six dimensions, namely, servant behavior, service strategy, serving oriented products, serving oriented processes, service culture and service leadership.

However, considering the act of hiring as part of the service-process for contracts effects, it is relevant to study the dimensions of serving oriented process in an adapted way. Thus, for an adapted application of the theoretical construct for serving oriented process to adhesion contracts, regarding orientation for serving specific contract, the dimensions of simplicity, flexibility, customer focus and information should be considered. 
INDEPENDENT JOURNAL OF MANAGEMENT \& PRODUCTION (IJM\&P)

http://www.ijmp.jor.br

v. 9, n. 1, January - March 2018

ISSN: 2236-269X

DOI: 10.14807/ijmp.v9i1.347

Nóbrega (2009) when dealing about the sense of serving, presents, as an example for a book author: when writing a text the author should keep in mind the clarity, objectivity of ideas and ease of understanding by the reader. He should endeavor to make it easy and affordable. The benefit of the reader is to understand clearly the content of the read text. If the author makes use of serving sense, he will write the text clearer and easier to understand.

For the purpose of a contract, simplicity dimension, which in theoretical construct of the serving oriented process suggests no formalities, complements clarity and transparency requirement addressed by Consumer Rights.

About flexibility in contracts, this can be interpreted with the prediction possibility of contractual clauses that visualize unpredictable situations, without giving the customer excessive burdens. In this aspect, the focus on customer, a contractual analysis, can be glimpsed when the contract covers exhaustively their rights and not just their obligations, in a way that there is a balance between rights and obligations.

Thus, the informative character, present in the theoretical construct of the serving oriented process and equally assured by the Consumer Protection Code, is reinforced by thesis related to the sense of serving, since the information is indispensable, including, for the success of service provision.

In synthesis, from the perspective of service-process, it seems interesting that contractual clauses visualize unpredictable situations, without giving the customers excessive burdens, inform the stages of execution of the service and the required behaviors of the customer, thoroughly present the rights of the contractor and are simple, direct, objective, with a less elaborated language, to fulfill the enlightening role of the service stage, namely hiring.

\section{SERVICE ORIENTED CONTRACT THEORETICAL CONSTRUCT}

The conceptual model of a service-oriented contract is the result of analysis of the interfaces between the serving oriented contract dimensions under the perspective of the Consumer Right, Service Management and Sense of Serving. The Figure 1 shows the Theoretical Construct of a serving oriented contract: 


\begin{tabular}{|c|}
\hline ACT \\
\hline DIMENSIONS AND ATTRIBUTES \\
\hline $\begin{array}{l}\text { DIMENSION: PHYSICAL ASPECTS } \\
\text { A1. Contract includes aspects of Physical Structure (Tangible Dimensions - Zeithaml, Parasuraman } \\
\text { and Berry, 1990; Adapted) } \\
\text { A2. Contract includes equipment used / needed (Tangible Dimensions - Zeithaml, Parasuraman } \\
\text { and Berry, 1990; Adapted) } \\
\text { A3. Contract includes The documents used / needed (Tangible Dimensions - Zeithaml, } \\
\text { Parasuraman and Berry, 1990; Adapted) } \\
\text { A4. Contract includes number of employees (Tangible Dimensions - Zeithaml, Parasuraman and } \\
\text { Berry, 1990; Adapted) }\end{array}$ \\
\hline
\end{tabular}

\section{DIMENSION: REASONABLENESS}

A5. Proportionate number of clauses which present rights and obligations to the client / contractor (Security Dimension - Zeithaml, Parasuraman and Berry, 1990; Adapted);

A6. Proportionality between the rights and obligations of the contractor (Balance Dimension Marques, 2013 Tartuce, 2011 and CDC - Brazil, 2014);

A7.Predictable situations of unpredictability, without giving excessive burden to the customer (Flexibility Dimension - Nobrega 2013 and Lopes Nobrega, 2013 Adapted);

A8. Making contractual cost of the contractor to be flexible. (Flexibility Dimension - Nobrega 2013 and Lopes Nobrega, 2013 Adapted);

\section{DIMENSION: INTELLIGIBILITY}

A9. Language simplicity (Clarity Dimensions / Transparency- Marques, 2013 Tartuce, 2011 and CDC - Brazil, 2014)

A10. Legible contract and conspicuous characters (Clarity Dimensions / Transparency - Marques, 2013 Tartuce, 2011 and CDC - Brazil, 2014)

A11. Lettering in readable size (Clarity Dimensions / Transparency - Marques, 2013 Tartuce, 2011 and CDC - Brazil, 2014)

A12. Comprehensive information on features, quality, quantity, composition, price, warranty, terms of validity and origin, among other data, as well as on the risks posed on health and safety, if any. (Clarity / Transparency Dimensions - Marques, 2013 Tartuce, 2011 and CDC - Brazil, 2014

A13. Contract objectivity (Reliability Dimension - Zeithaml, Parasuraman and Berry, 1990; Adapted)

A14. Technical terms clarification (Reliability Dimension - Zeithaml, Parasuraman and Berry, 1990; Adapted)

A15. Process clarification, with the explanation of the stages of execution of the service (Information Dimension / Simplicity -Nóbrega 2013 and Lopes Nobrega, 2013 Adapted)

A16. Customer conduct explanations (Information Dimension / Simplicity Nobrega 2013 and Lopes Nobrega, 2013 Adapted);

A17. Harmful clauses highlights to the customer (Clarity Dimensions / Transparency Marques, 2013 Tartuce, 2011 and CDC - Brazil, 2014

\section{DIMENSION: CUSTOMER FOCUS}

A18. Abusive terms elimination (Good faith Dimension - Marques, 2013 Tartuce, 2011 and CDC Brazil, 2014);

A19. Proposed service with possibilities of execution as promised (Good faith Dimension - Marques, 2013 Tartuce, 2011 and CDC - Brazil, 2014);

A20. Highlighting of clauses that present rights to the client / contractor (Customer Focus Dimension - Nobrega 2013 and Lopes Nobrega, 2013 Adapted);

A21. Prediction deadline (Responsiveness Dimensions / Empathy -Zeithaml, Parasuraman and Berry, 1990; Adapted);

A22. Reasonable time prediction for service execution (Responsiveness Dimensions / Empathy Zeithaml, Parasuraman and Berry, 1990; Adapted);

A23. Service personalization prediction (Responsiveness Dimensions / Empathy -Zeithaml, Parasuraman and Berry, 1990; Adapted);

Figure 1: Theoretical construct of a serving oriented contract.

Source: 2014 Research. Marques (2013), Tartuce (2011), CDC (Brasil 2014), Nóbrega (2013), Lopes e Nóbrega (2013), Zeithaml, Parasuraman e Berry (1990); Adapted 
Physical aspects, part of the service tangible aspect, consists on verification if the contract includes aspects of physical structure, equipment, necessary documents, persons, specially for services where such requirements are necessary and relevant.

Reasonability dimension is related to analysis of balance and proportionality of clauses that deal with rights and duties for the contractor. Apart from that, in the perspective that can be considered reasonable, verification of an excessive burdensome to the customer and the inclusion of clauses that protect, in some way, unpredictable situations, without the cause of loss to the contractor, may be glimpsed to this specific dimension.

However, intelligibility brings a conceptual notion of that, which is intelligible, is something that is easily understood, simple comprehension. Thus, it transmits clarity and accessibility ideas. Therefore, it is the dimension that covers the type of contract language, presence of conspicuous and legible characters, lettering size, amplitude information, simplicity, objective character, explanation of technical terms, information about the stages of service process, instructions directed to client, highlights of harmful clauses to the contractor and exemption of errors.

Finally, the proposed conceptual model suggests a fourth and final dimension, called customer focus, which refers to the concepts of good faith, responsiveness and contractual readiness. It is justified by verification of abusive clause or that which presents burdensome to customers, as well as analysis if contract thoroughly exposes customers' rights. It also includes study of loyalty of contractual proposal and established deadline. Moreover, even if the proposed theoretical construct is destined to adhesion contracts, elaborated unilaterally by organizations providing service, it is somehow possible that, the contractual instrument glimpse forms of service personalization, showing focus on serving the customer.

Thus, based on the theoretical model for service oriented contract, a research was carried out, which scaled the degree for the sense of serving adhesion contracts proposed by companies providing subscription TV service.

\section{METHOD}

This research was conducted regarding 5 Cable TV companies, whose services are commercialized through subscription, in order to analyze their adhesion 
INDEPENDENT JOURNAL OF MANAGEMENT \& PRODUCTION (IJM\&P)

http://www.ijmp.jor.br

v. 9, n. 1, January - March 2018

ISSN: 2236-269X

DOI: 10.14807/ijmp.v9i1.347

contract profile. Companies with greater activity in Brazilian State of Rio Grande do Norte were selected, and their contractual instruments were analyzed, aiming to verify to what extent company contracts show service orientation. Although the studied companies also include, in their services overall offer, telecommunication and mobile phone services, this research was limited to Cable TV services.

The analysis consisted of evaluation of each adhesion contract, in total of five, by eight law professionals, named judges. These judges were chosen by accessibility criteria, once this study required a specialized knowledge (Law Graduation), and it would count with deepen analyze. Although this context, some care was taken, such as: they could not be professional related with any of the companies; they should be graduated for more than 10 years; they should be preferable related to Law teaching; they would not access the company names, minimizing possible bias.

There was a script with 4 dimensions, corresponding to 23 attributes, related to the theoretical construct for the service-oriented contract (Figure 1). The research instrument provided, for each attribute, three options of response, corresponding to: a. the contract does not contemplate the attribute; b. the contract contemplates moderately the attribute; c. the contract adequately contemplates the attribute. Besides the attributes, there was an additional question, regarding an overall evaluation about the contract level of serving orientation. A scale was used, going from 1.0 for option a (does not contemplate), to 3.0 (adequately contemplates), presenting 2.0 for the option "contemplates moderately".

Data were collected through disposal of printed forms instrument, and the researcher waited nearly for the complete answer. Eventually some orientation was needed at the beginning of the process, but the researcher took care in not discussing content of the attribute. Considering that 23 attributes of 5 five companies should be evaluated, an amount of 115 items were analyzed by each judge.

By opportune, taken the data from the judges evaluations, it was noticed, initially, that all the 24 items evaluated by the 8 judges obtained an Cronbach's alpha ranging between 0.722 and 0.762 , alias, with data consistency rated as satisfactory (NUNNALLY, 1978). 
INDEPENDENT JOURNAL OF MANAGEMENT \& PRODUCTION (IJM\&P)

http://www.ijmp.jor.br

v. 9, n. 1, January - March 2018

ISSN: 2236-269X

DOI: 10.14807/ijmp.v9i1.347

To verify the concordance degree of the judges (specialists) for the evaluated contracts, Kappa test was applied, which resulted in a poor or regular concordance among the judges value 0.31), considering the variations analysis and provided response (LANDIS; KOCH, 1997).

Thus, to give greater security to the results, the Content Validation Index (CVI) was used, calculated by comparing the individual assessment of a judge with the assessment of others, calculating the CVI for each pair of judges (WALTZ; STRICKLAND; LENZ, 1991).

The overall average of CVI was 0.73 , when the validation value cutoff point is above 0.78 or 9.0 (ALEXANDER; COLLUCI 2011). So, some simulations for attributes exclusions were made. By excluding $A 3, A 4, A 7, A 18$ and $A 20$ attributes, a CVI of 0.81 was found, attending referred minimum of 0.80 (DAVIS, 1992; GRANT; DAVIS, 1997) but this meant eliminating 5 variables. So, finally with attributes $A 3$, A4, and A7 exclusion, a CVI of 0.78 was obtained, attending referred recommendations (ALEXANDER; COLLUCI 2011; POLIT; BECK, 2006; LYNN, 1986).

\section{RESULTS}

According to the $\mathrm{CVI}$ and the overall evaluation of the requirements for Cable TV contracts, $41.71 \%$ of them were considered adequate, presenting serving orientation, as it is shown in Table 1.

Table 1: Content Validity Index

\begin{tabular}{|l|r|r|}
\hline \multicolumn{1}{|c|}{ Classification } & Frequency & \multicolumn{2}{c|}{ Percentage } \\
\hline Contract does not contemplate & 159 & 16.58 \\
\hline Contract insufficiently contemplates & 400 & 41.71 \\
\hline Contract adequately contemplates & 400 & 41.71 \\
\hline \multicolumn{1}{|c|}{ Total } & 959 & 100.00 \\
\hline
\end{tabular}

Source: Research

From the overall 959 evaluations, 559 (58.29\%) of the items presented an unsatisfactory analysis from the evaluators, since they remit to aspects "not contemplated", or "insufficiently contemplated". It is tempting to affirm that the researched contracts are non-servant oriented, due to this level of noncontemplation. But it seems to be recommendable conduct more researches, including more services for the same studied companies, as well as the inclusion of 
INDEPENDENT JOURNAL OF MANAGEMENT \& PRODUCTION (IJM\&P)

http://www.ijmp.jor.br

v. 9, n. 1, January - March 2018

ISSN: 2236-269X

DOI: 10.14807/ijmp.v9i1.347

other companies, is a future research. It is also necessary register the innovative character of this research.

However, even if the overall evaluation has not revealed satisfaction in the contracts evaluation, after the application of parametric statistical tests MANOVA (Multivariate Analysis of Variance) and Tuke test, it was found that, among the four dimensions evaluated, two of them presented better performance: intelligibility and customer focus. Table 2 shows the arithmetic averages, in decreasing order, of the questions relating to the four dimensions:

Table 2: Descriptive statistics of the researched dimensions

\begin{tabular}{|l|r|r|r|r|r|r|}
\hline \multicolumn{1}{|c|}{ Dominances } & \multicolumn{1}{c|}{ Minimum } & Maximum & \multicolumn{1}{c|}{ Median } & Mean & \multicolumn{1}{c|}{ SD } & \multicolumn{1}{c|}{ CV } \\
\hline Intelligibility & 2.00 & 2.89 & 2.56 & 2.52 & 0.27 & 10.56 \\
\hline Customer Focus & 1.83 & 2.83 & 2.33 & 2.31 & 0.26 & 11.41 \\
\hline Reasonableness & 1.25 & 3.00 & 2.00 & 1.97 & 0.47 & 23.92 \\
\hline Physical aspects & 1.00 & 2.75 & 1.75 & 1.81 & 0.44 & 24.38 \\
\hline \multicolumn{7}{|c|}{ Source: Research }
\end{tabular}

Taking both mean values from Table 2, the best-ranked dimensions were: intelligibility (2.52), customer focus (2.31). To both dimensions, standard deviation were smaller $(0.27$ and 0.26$)$. This reveals some concordance with literature regarding serving and costumer oriented approach (NÓBREGA, 2013; GRÖNROOS, 2015, LEFAUVE, 1994; SHAMMA; HASAN, 2013). A possible justification for that may be the increasing care with clearness, notably due to consumer rights respect and quality conscientiousness by customers. It seems also revealing to look at the minimum values for both dimensions, which were the biggest minimum values $(2.00$ and 1.83 , respectively), both bigger than the theoretical median (1.5).

On the other hand, physical aspects ranked in fourth position (1.81) corroborates Zeithaml, Berry and Parasuraman's order of importance for Servqual dimension "physical aspects" (1991), reasonable (1.97) and physical (1. 81) were observed.

Reasonableness and Physical aspects dimensions, with average ranked in third and fourth positions $(1.25 ; 1.00)$, presented minimum values around the theoretical minimum (1.00), as well as the biggest standard deviations $(0.47 ; 0.44)$. A possible explanation for that is the great variety for points of view on defining reasonableness - reasonableness may be unreasonable? (ZEITHAML; BITNER, 
2003; TARTUCE, 2011; MARQUES, 2013), and, in case of "physical aspects", the difficulty in making service tangible (ZEITHAML; BITNER, 2003).

\section{CONCLUSIONS}

To serve versus to be served: what is most present in service companies? Which one tends to be more present in service companies contracts? This was the motivation for the present research.

Through joining two great research fields - law and service management, this research faced the challenge of constructing a theoretical construct and use it to evaluate the existence and identify the level of serving orientation in adhesion contracts offered by Cable TV companies operating in a determined region. Four dimensions compose the proposed construct: Intelligibility, Customer Focus, Reasonableness and Physical Aspects.

Results indicated that, as an overview, the researched contracts presented low serving orientation, and that, among them, none of the companies releases a contract that can be considered best rated or best serving orientated.

On evaluating service oriented contract dimensions, it was possible to identify that the dimensions pointed out as better evaluation were Intelligibility and Customer Focus. On the other hand, Reasonableness and Physical Aspects dimensions presented the lowest serving orientation.

From the perspective of management implications, the study presents important practical efficacy, because it can guide subscription TV companies to adopt improvement strategies when elaborating contracts, so that the contractual instruments can be fulfilled with clauses that promote sensation of better service to their customer. At the same time, the research presented results that can direct managers to the aspect that deserves more attention, i.e., which dimensions require further refinement and direction to serve, naturally according to each operation nature and segment of service.

It was objective of the present study to deal with adhesion contracts, as a first study on serving orientation. Due to this reason, a segment of service was chosen: Cable TV. But there are several other service segments, which also make use of adhesion contracts, like credit card, bank account, health plans, life insurance and others. By expanding the list of such organizations, the utilization of this theoretical 
construct may be applied to other companies, other segments, and other services, adopting and/or adapting the presented attributes.

The companies considered in this researched also offer telecommunications and mobile phone services, it is suggested that future researches evaluate the contract for the other provided services.

Due to the innovative characteristics of this research about service oriented contracts, it seems important to point that frequent argumentations about the tendency to elaborate law directional content, assuming a posture to defend providers, much more than deliver clear information, describing service results and benefits to customers might be a topic for research.

In this sense, the fact of not having included customer point of view, in this first moment, can be defended by the argument that contracts evaluation by law professionals would be a representative starting point. But including customers, in a future moment, may be an enrichment approach.

Finally, it is indicated that future researches can analyze which dimensions and attributes are considered more relevant to the general perception of the contracts like to analyze the relevance of the service oriented contract to the customer and the influence of contracts on service quality.

\section{REFERENCES}

ALEXANDRE, Neusa Maria Costa; COLUCI, Marina Zambon Orpinelli. Validade (2011) conteúdo nos processos de construção e adaptação de instrumentos de medida. Ciência e Saúde Coletiva, v. 16, n. 7, p. 3061-3068.

BRASIL. (2014) Código Civil. Senado Federal. Brasília: Gráfica do Senado.

BRASIL. (2014) Código de Defesa do Consumidor. Senado Federal. Brasília: Gráfica do Senado.

Davis L. L. (1992) Instrument review: getting the most from a panel of experts. Appl Nurs Res, v. 5, n. 4, p.194-197.

FITZSIMMONS, James A.; FITZSIMMONS, Mona J. (2005) Administração de serviços: operações, estratégias e tecnologia da informação. 4. ed. Porto Alegre: Bookman.

GRANT J. S., DAVIS L. L. (1997) Selection and use of content experts for instrument development. Res Nurs Health, v. 20, n. 3, p.269-274.

GRÖNROOS, Christian (2015) Marketing: gerenciamento e serviços. 3. ed. Rio de Janeiro: Elsevier. 
GRONROOS, Christian (2006) Um Modelo de Qualidade de Serviços e suas Implicações para o Marketing. Revista de Administração de Empresas, v. 46, n. 4. Out/Dez.

KOTLER, P.; KOTLER, M. (2013) Marketing do Crescimento. Rio de Janeiro: Campus.

LANDIS, JR.; KOCH G. G. (1997) The measurement of observer agreement for categorical data. Biometrics; n. 33, p. 159-174.

NÓBREGA, K.; WHEBBER, P. (2010) Servant organization: a comprehensive approach about the servant behavior from the customer point of view. 2010 POMS Annual Conference Proceedings, v.1. Vancouver: POMS.

NÓBREGA, K.; LOPES, A. (2013) Classificação de Serviços e sua Interface com os Processos Servidores. XVI Simpósio de Administração da Produção, Logística e Operações Internacionais, São Paulo, 28-30 de agosto, p.1-15.

LEFAUVE, R. G. (1994) Building a Customer-driven Company - The Saturn Story: An Interview between Richard G. Lefauve, Saturn Corporation, and Richard Whiteley, of the Forum Corporation. Managing Service Quality: An International Journal, v.4, n. 5, p.16-21.

LOVELOCK, C.; WRIGHT, L. (2011) Serviços: Marketing e Gestão, São Paulo, Saraiva.

MARQUES, C. L. (2005) Contratos no Código de Defesa do Consumidor: o novo regime das relações contratuais. $5^{\circ}$ ed. São Paulo: Editora Revista dos Tribunais.

MOLNAR, Darin R. (2007) Serving the world: a cross-cultural study of national culture dimensions and servant leadership. Tese de Doutorado em Filosofia na Universidade Capella, EUA.

NÓBREGA, K. C. (2012) Empresa Servidora: como o comportamento servidor pode ser expandido para uma abordagem organizacional. PERCEPTUM Assessoria e Desenvolvimento. Natal/RN, p. 92.

NÓBREGA, K. C. (2009) Servant organization: how individual behavior can be expanded to a business approach. POMS 20th. Orlando, Florida USA.

NÓBREGA, K. C.; RIBEIRO, S. R. M.; MARQUES, V. (2006) O Senso de SERVIR Fortalecendo a Competitividade Empresarial: o caso de um supermercado.XXVI ENCONTRO NACIONAL DE ENGENHARIA DE PRODUÇÃO, Anais...Fortaleza, CE: ENEGEP, outubro.

NÓBREGA, K. C. (2009) Empresa servidora: como o comportamento individual pode ser expandido para uma abordagem organizacional. POMS 20th Annual Conference Orlando, Florida U.S.A. May 1 to May 4, p. 11.

NÓBREGA, Kleber Cavalcanti; OLIVEIRA, Patrícia Whebber Souza de; SOUZA, Tereza de. (2007) Gestão do Desempenho baseado no Senso de Servir. Revista Gestão e Planejamento. v. 8, n. 2, p. 61-77, jul./dez.

NÓBREGA,K.C et al. (2009) Grönroos strategic competition perspectives: the case of pizza delivery. POMS 20th Annual Conference Orlando, Florida U.S.A. May 1 to May 4.

NUNNALLY, J. C. (1978) Psychometric theory. 2a ed., New York, McGraw, p. 152. 
PARASURAMAN, A.; ZEITHMAL,V. A.; BERRY, L. (2006) Um modelo conceitual de qualidade de serviço e suas implicações para a pesquisa no futuro. Revista de Administração de Empresas - RAE, v. 46, n. 4, p. 104.

PARASURAMAN, A. et al. (2009) Process completeness: Strategies for aligning service systems with customers' service needs. Kelley School of Business, Indiana University. Business Horizons: Elsevier.

PARASURAMAN, A.; ZEITHMAL,V. A.; BERRY. (1990) Delivering Quality Service - Balancing Customer Perceptions and Expectations. New York: Simon \& Schuster Inc.

POLIT, D. F.; BECK, C. T. (2006) The content validity index: are you sure you know what's being reported? Critique and recommendations. Res Nurs Health, v. 29, p. 489-497.

LYNN, M. R. (1986) Determination and quantification of con- tent validity. Nurs Res, v. 35, n. 6 , p. 382-385.

SHAMMA, H.; HASSAN, S. (2013) Customer-driven benchmarking: A strategic approach toward a sustainable marketing performance. Benchmarking: An International Journal, v. 20, n. 3, p. 377-395.

SILVESTRO, R.; FITZGERADL, L.; JOHNSTON,R.; VOSS,C. (1992) Towards a classification of service processes. International Journal of Service Industry Management, v. 3, n. 3, p. 62-75.

TARTUCE, F. (2011) Manual de Direito Civil. 2ªEd. São Paulo: Editora Método.

WALTZ, C. F.; STRICKLAND, O. A.; LENZ, E. R. (1991) Measurement in nursing research. Second edition. Philadelphia: F.A. Davis Co., 1991.

YOSHIMURA, K. (1996) Encontro de coordenadores de TQC: Qualidade na prestação de serviços. III Seminário Catarinense de TQC. Florianópolis. Outubro.

ZEITHAML, V. A.; BITNER, M. J. O. (2003) Marketing de serviços: a empresa com foco no cliente. Porto Alegre: Ed. Bookman.

ZEITHMAL, V. A. et al. (1997) Customer contributions and roles in service delivery. International Journal of Service Industry Management, v. 8 n. 3.

ZEITHAML, V. A.; PARASURAMAN, A.; BERRY, L. (1990) Delivering quality service: balancing customers perceptions and expectations. New York, Free Press. 